\title{
EFFICACY OF METHODOLOGICAL PRACTICES UNDERTAKEN BY SAUDI ENGLISH TEACHERS IN PUBLIC SCHOOLS DURING THEIR FORMATIVE PHASE
}

\author{
Majed Othman Aba Hussain \\ College of Education, Majma'ah University, Kingdom of Saudi Arabia \\ Email: m.abahussain@mu.edu.sa \\ Muhammad Iqbal \\ Department of English, College of Education, Majma'ah University, Kingdom of Saudi Arabia \\ Email: m.Iqbal@mu.edu.sa \\ Imran Khan \\ Department of English, College of Education, Majma'ah University, Kingdom of Saudi Arabia \\ Email: imkk2020@mu.edu.sa
}

\begin{abstract}
APA Citation: Hussain, M. O. A., Iqbal, M., \& Khan, I. (2019). Efficacy of methodological practices undertaken by Saudi English teachers in public schools during their formative phase. English Review: Journal of English Education, 7(2), 47-54. doi: 10.25134/erjee.v7i2.1774.
\end{abstract}

Received: 28-01-2019

Accepted: 30-03-2019

Published: 01-06-2019

\begin{abstract}
The main focus of this article is to evaluate the practices involving various approaches and methods that the novice Saudi English Teachers (SETs) employ in classrooms, and to see how far these are successful in attaining the desired results. It also takes into cognizance the chasm between the measures taken by Saudi Ministry of Education to modify the curriculum to develop "communicative competence" and the actualization these measures in the classroom pedagogy. The dichotomy eventually brings to bear upon the learning outcomes of the students who fail to achieve the required proficiency in communicative skills. The study necessitated a qualitative approach (grounded theory) in which previous literature was ransacked. Data was gathered through structured interviews, surveys and documents analysis. The rudimentary results showed that SETs rely more on conventional teaching methods despite the State's thrust on Communicative Language Teaching (CLT) that tends to be more student-centered, cooperative and collaborative.
\end{abstract}

Keywords: communicative competence; grounded theory; teaching approaches; teaching methods.

\section{INRODUCTION}

The importance of teaching English in Saudi schools has grown tremendously over the last two decades. This impetus largely emanates from the process of globalization in which communication by means of English dominates commerce, trade, social media, research and publications (Flowerdew \& Peacock, 2001). Saudi government is also very keen to give incentives to both learners and teachers by allocating a huge amount in the budget exclusively for teaching and learning English (SAMA, 2015). However, despite all the efforts, Saudi schools are not able to yield the desired learning outcomes. One of the major reasons for this problem is ascribed to the infirmities in the method and practices of teaching and learning English. Inadequate training of the teachers, flawed inappropriate teaching methods and teacher-center environment in the classroom hamper the process of attaining proficiency in English for communicative purposes (Fareh, 2010).
Taking cognizance of these challenges, Saudi Ministry of Education (MoE) has taken multiple drastic measures to bring about reforms in the existing education system, specifically in teaching English as a foreign language (TEFL) elaborating its general goals and targets in Saudi Arabia (Alhajailan, 2006). The reforms included the designing of news textbooks based on Communicative Teaching Method (CLT), training the teachers abroad, improving the process of English teaching and learning in Saudi schools under English Development Project (ELDP) in 2007, and collaborating with British and American publishing companies (Alabdualkarem, 2007). Besides, seminars and conference were also held to address the problem of inadequacy in TEFL (Rahman, 2011). Nevertheless, the problem persists for lack of employing Communicative Language Teaching (CLT) by the English language teachers who continue to rely more on traditional methods. Hence, it is worthwhile to explore the prevailing 
situation for finding the facts to tackle the stated problem in a better way.

\section{The introductory phase}

Alesghayer (2011) alludes to the fact that teaching and learning of English language had been in practice in some areas prior to becoming a component of scholastic curriculum in 1944. The same is marked by the introduction of EFL to Saudi educational curriculum. The thrust of the prescribed textbook had been on reading, writing, grammar and translation. The teachers, therefore, resorted to Grammar-Translation Method (GTM) combined with rote learning of English words translated in the first language (Alhajailan, 2006). However, in late 1950s, GMT began to receive harsh criticism, and resultantly, the Saudi educationists responsible for policy making shifted to develop oral skills through teaching and learning English (Alseghayer, 2011a).

\section{The reformative phase}

This phase commenced around 1958. Again, Alhajailan (2006) makes an overview of the changes that occurred onward. School system was reorganized. In order to improve the oral skill of the students, new textbooks - 'Living English for the Arab World', 'A Traveller's Cheque', 'The Pearl', and 'Round the World in Eighty Days' - were introduced. These books had been used for two decades mainly using Audio-Lingual Method (ALM). All this got inspiration from the EFL/ESL theories that emerged during the World War II, largely emphasizing oral practice, pronunciation and mechanically teaching and learning a new language (Richards \& Rogers, 2001). According to Hall (2011), at that time, ALM was a popular method as it offered an amalgam structuralism and behaviorism. However, the validity of this method embraced questioning during 1970s in Saudi Arabia as well exactly in line with criticism of this method the world over. Linguists like Chomsky came up the conviction that imitation and drilling cannot enable children to speak a language outside the classroom as it is imbibed with gross irregularities in practical life (Karunakran \& Babu, 2013).

\section{The communicative phase}

Once again, the studies conducted by Alhajailan (2006) and Alseghayer (2011a), show a shift in Saudi Ministry of Education policy when "a new textbook entitled 'Saudi Arabian Schools English' was introduced in collaboration with Macmillan Press in 1981 onward, adopting Communicative Language Teaching (CLT) approach in the curriculum" (Howatt 1984). The textbook contents dealt with some theme, function or notion with a variety of interactive activities (pairing and sharing, group tasks and discussions) to enable the learners to communicate in real life situations. In 2004, another text book 'Say It in English' with more interactive activities was prescribed in the syllabi. The same year, English was introduced as a compulsory subject in the elementary section. The year 2008 witnessed the launching of new program namely "English Language Development Project" (ELDP) that aimed to streamline the existing English curriculum in collaboration with Macmillan, McGraw Hill, Pearson Longman and Oxford University Press (British and American textbook publishers for EFL and ESL). This was in pursuance of principles devised for CLT, i.e. "a language is a system for communication; it should have an integration of communicative activities in all the units and all such activities should emanate from the contents, function and meaning" (Howatt, 1984; Berns, 1990; Brown, 2007; Hadley, 2001). Riyadh, Saudi Ministry of Education (2015) did say that the new textbooks, if handled professionally by the teachers, can give a boost to the confidence of the students and enable them to use English to communicate competently with people in real life.

Communicative language teaching approach and communicative competence

A peep into already available literature on the subject reveals that Communicative Language Teaching (CLT) evolved in the 1970s visualizing language as a system for communication leading the learner to attain communicative competence (Hymes, 1971; Halliday, 1973; Richards \& Rodgers, 2001). Two components - "What to teach" and "How to teach" - are emphasized in CLT (Harmer, 2001). Littlewood (1981) also impressed upon the need of systematic focus on functional as well structural dimensions of language. Then, Chomsky came up with a distinction between 'competence' and 'performance' - the former referring to the grammatical system for generating infinite sentences, and the latter referring to the communication of knowledge that underlies (Newby, 2011). Chomsky's concept was further rationalized by Canale and Swain (1980) to encompass four elements i.e. grammatical competence, socio-linguistic competence, discourse competence and strategic competence. The mastery of all these concepts is, therefore, essential for the teachers to implement in the 
classroom and also regulate the role of the learner for that matter.

\section{Teacher's and learner's role in CLT}

Breen and Candlin (1980) envisages the role of a teacher in CLT as a facilitator, a guide, and an organizer. Rather than being authoritative, the teacher should work as a "co-communicator, an analyst of needs, an organizer of resources, a facilitator of activities and a learner (LarsenFreeman, 2001). The learner in CLT is, however, expected to be a negotiator of meaning, a discoverer as well as contributor of knowledge and information (Hu, 2002). Brown (2007), too, thinks that "the learner in CLT classes should actively participate in the classroom proceedings based on leaner-centered, cooperative and collaborative learning processes.

\section{METHOD}

"Which methodological practices do Saudi English Language teachers in their formative year in state schools use in their classrooms?" and "How successful are these?" are the questions that warrant two-pronged investigation; i) exploring and describing the existing situation, and ii) interpreting why this happens (Punch, 2009). According to Birks and Mills (2011), such a research inquiry has to understand "reality" in terms of ontology (What is the nature of reality?), epistemology (What is the relationship between the researcher and the participants?) and methodology (How can the knowledge be gained?). Out of multiple methodologies handling naturalistic and interpretive inquiry, grounded theory (Glaser \& Strauss, 1967) has been chosen as rigorous and systematic methodology of data collection and data analysis.

The population of this study comprises Schools of Education, Schools of Arts, and Schools of Language and Translation. As for sampling, a strong group of 114 Saudi English language teachers from the above mentioned three channels was targeted. Besides, the supervisors who monitor the SETs performance and the lecturer who teach teaching methods in teachers' training program have been consulted for building a comprehensive picture of the reality.

Employing the procedure of Grounded Theory, data was gathered by two means - i) data generation and ii) data collection. For generating data, interviews were conducted with participants in close proximity. This gave a better understanding of what goes on (Birk \& Mills, 2011). For collecting data, "elicited materials such as questionnaire" were used. Besides, documentary sources like official documents, reports and textbooks ransacked to dig out the facts relating to the issue that is under scrutiny in the study. In order to ensure the reliability of the questionnaires, a preliminary survey was conducted by sending them to a small segment of the sample comprising only ten teachers with an interval of two months to check if the items in the questionnaire yielded the identical responses showing consistency irrespective of the time passage (Punch, 2009). For internal reliability, independent variables were limited to the preparation that Saudi English teachers make before joining the public schools just to focus on their formative years. Content validity was also ensured by covering all the dimensions and getting them vetted by a set of experts.

\section{RESULTS AND DISCUSSION}

The evaluation of a change necessitates an appraisal of the existing practices carried out by the people responsible for introducing new measures (Bowers et al., 2007). It is also debated that the implementation of a new teaching method is dependent upon the teachers' role played in the classroom (Chowdhury, 2012). The data gathered during the research demonstrated that SETs were primarily transmitter of knowledge in the formative phase of their career. Thirty-six teachers who responded to the questionnaire and 8 who were interviewed, admitted their role as knowledge transmitters. For instance, one of the responders said:

"I think I am mostly doing the transmitter role. I spend most the lesson time in lecturing and explaining grammatical rules."

While doing so, not only did they turn out to be the most trusted source of knowledge, but also become the determiners of classroom activities. The statement of one teacher goes as follows:

"I have to prepare and execute most of the classroom activities......myself, and I rarely share this job with my students because I believe they are not capable of doing such a job with their limited English."

Another fact that came to the fore in the collected data deals with the massive dependence on text books for transmitting knowledge. The transcription of one of the interviewee goes like this:

"I abide by what is in the text book, and most of my activities are also around the textbook material and my questions also most test what students have acquired from the text book." 
Heavy reliance on lectures by the teacher was found in the responses of the questionnaires and interviews. Forty-two teachers while responding to a question as well as to an inquiry in the interviews related to their role as a lecturer avowedly admitted to have followed lecturing style whatsoever. As an instance, the reply of a teacher is reproduced below:

"Generally, for the most of the class time, I have to use lecturing or demonstrating as a teaching style. I present the main topic, write the important words on the board, explain grammar rules, translate the new words, read the text and ask some questions for verification."

Managing the class by a teacher is highly challenging in schools, in particular (Fantilli \& McDougall, 2009). Six years of experience of the researcher in Saudi school as a supervisor, exhaustive discussion with the colleagues, and the date gathered (91\% of samples of the interview) revealed that the authoritative role of the teacher is a 'must' to control the students in Saudi schools. A slight latitude on the part of the teacher in the class resulted in chaos and a noise. So, even pair and group activities are avoided as the administrators of the school lay stress on strict discipline and quietness. Surprisingly, only $5 \%$ of the interviewees acknowledge their role as a facilitator.

As outlined in Table 1 below, the questionnaire results show that 41 Saudi English Teachers (SETs) resorted to teacher centered approach at the outset of their career in EFL classroom, whereas only 4 teachers preferred to adopt student-centered approach in their teacher practices. Similarly, the percentage of teachers' interviews turned out to be the same.

Table 1. Dominant teaching practice

\begin{tabular}{cccc}
\hline Sample & Teacher-centered approach & Student-centered approach & Total \\
\hline Teachers' questionnaire & 41 & 4 & 45 \\
Teachers' interview & 11 & 1 & 12 \\
\hline
\end{tabular}

In addition, "traditional structured based approach" is followed in Saudi schools English classes primarily aiming at meaningful language (Maria, 2006). The information derived by means of questionnaire and interviews displays a routine that is repeated in the classroom, i.e. the teacher presents the lesson as a lecturer, reads the text, translate the difficult words, writes the new words on the board, pronounces them, teaches grammatical structures, and gives some exercises for practice. Finally, a few questions are asked by the teacher to get feedback about what has been taught. The number of students participating in the proceedings is also very limited, devoid of any conversation for that matter. The remarks given by a teacher in the interview are worth mentioning here:

"Generally teaching techniques have more reliance on using the board for writing and presenting information. My thrust remains on providing the learners with adequate information and asking them to jot down the key points in their notebooks. Much of the lesson is devoted to teaching grammar and new or difficult words as it my conviction that the skills improve students' writing ability. " (Transcription)

The answers also indicate that only one skill or sub-skill (such as grammar, translation, vocabulary, pronunciation etc.) as illustrated in Figure 1 is focused during the lesson.

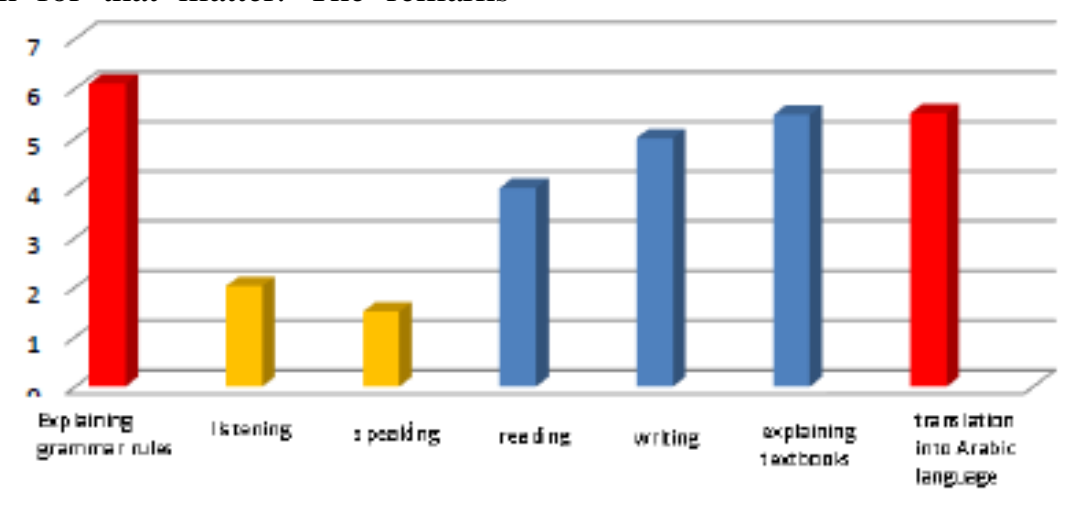

Figure 1. Skills or sub-skills give more emphasis in teaching practice 
As per the above figure regarding the weightage received by main skills and sub-skills like grammar rules (6 out of 7), explaining textbooks and translation into Arabic language (5.5 out of 7 respectively) got the highest priority whereas the main skills of communication, i.e. listening, speaking, reading and writing receive less importance $(1.9,1.2,3.9$, and 4.9, respectively). Likewise, the replies to Question 1 in the interview and Question 9 in the questionnaire, demonstrate that majority of the participants (around 95\%) use deductive method in which grammatical rules are explained by the teachers and notes are passively taken by the learners. Translation of new words into Arabic language is also resorted to drive the meanings home.

The aforementioned findings clearly show that Grammar-Translation Method (GMT) is largely practiced by the Saudi English Teachers (SETs). This fact is accentuated by the data gathered wherein 42 teachers as participants in the questionnaire and 11 out of those who were interviewed declared explicitly or implicitly the massive use of GMT as a teacher practice. Similarly, reading and writing skills get greater weightage for the sake of the final exam. Listening and speaking, however, receive the least weightage for want of language labs and authentic material, and also because the final exam assessment ignores them. The teacher's responses to Question 10 (questionnaire) and Question 1 (interview) reveal the integration of oral skills not communicative objectives but for structural reinforcement of the language. This also involved mainly the Audio-Lingual Method (ALM) for repetition and controlled-drilling for accurate pronunciation of individual words rather than expressions, as is termed by Richards and Rodgers (2001). As such, Saudi English Teachers (SETs) blindly rely on the textbook contents, repetition, memorizing, drilling, and rote-learning just to make the students get through the exams, making the whole process teacher-centered.

A critical analysis of the findings simply leads one to conclude that methodological teaching practices undertaken by Saudi English Teachers (SETs) largely revolve round transmitting knowledge. What the SETs do in the classrooms is set to achieve this objective. Even, roles played by the teachers and students, materials for teaching and assessment methods are directed to transmission of knowledge only. So to say, the concept of "education as a product" rather than "as a process" is in vogue (Welker 1992; Nunam
1988). In other words, "mimetic teaching" as termed by Jackson (1986) cited in (Christopher, 2012) is focused more wherein one person (the teacher) endeavors to transmit knowledge to another person (learner) with precision and smoothness by means of drilling, controlled practice, rote-learning and deductive methods. As the flow of knowledge is fully controlled by the teacher and the student has to tap it passively on the other end, Broughton (1994, p.22) terms it "teacher-dominated interactions" as a kind of practice. Then, transmission of knowledge is coupled with Grammar-Translation Method (GMT) as the meanings of words and the explanation of grammatical structures are rendered in Arabic language. Now this knowledge is worthless unless it is memorized through drilling and oral repetitions that fall within the purview of Audio-Lingual Method (ALM).

Moreover, since the main concern of SETs' teaching practice is the amount of knowledge that has to be transferred to students, the process is confined to teaching isolated skills what is termed as 'synthetic approach' by Wilkins (1976). Although the language skills are taught by SETs separately, they also vary in terms of importance. The skills pertaining to grammar and translation are focused more as compared to listening, speaking, reading, and writing. This goes in line with Alseghayer's (2011b) findings showing that English teachers who teach in Saudi schools devote their teaching practices as follows: $32 \%$ to grammar, $30 \%$ to translation, $17 \%$ to reading, $12 \%$ to writing, and $9 \%$ to speaking. This could be referred to the traditional approach in which first priority is given to grammatical competence for the sake of laying foundation of language proficiency, and then the four basic skills are introduced (Ozsevik, 2010).

In summary, the aforementioned practices undertaken by Saudi English Teachers (SETs) in Saudi schools pertain to the methods that are traditional in their approach assigning a dominant role to the teacher and marginalizing the interaction of learners, concerning more with the ultimate product of teaching rather than focusing on teaching-and-learning process in which cooperative and collaborative learning plays a key role leading to a student-centered environment. Figure 2 below gives a clear picture of the current teaching practices that the SETs adopt in the classrooms during their formative years. 


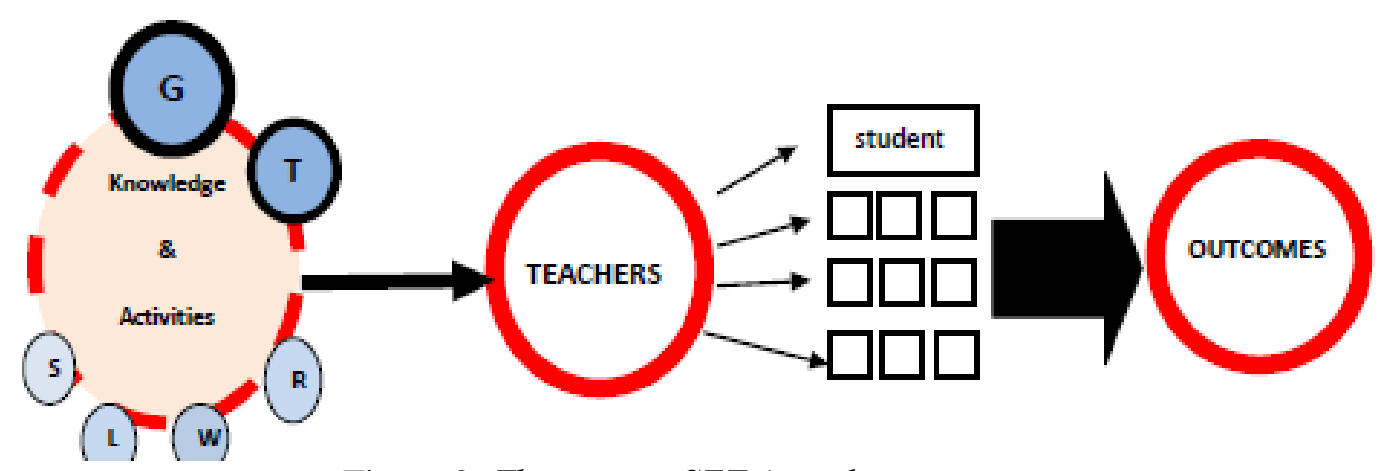

Figure 2. The current SETs' teaching practice

The size of the circles on the left in the above figure shows the amount of emphasis given to various skills. Grammar $(\mathrm{G})$ and Translation $(\mathrm{T})$ as discrete skills are given more weightage by the teachers as compared to oral skills which receive less importance. The gaps in oval circle on the left also allude to the fact that the skills are taught in isolation without any integration. The presenter of these skills is the teacher who plans and organizes them in teaching process arbitrarily. The students' role seems to be peripheral in the classroom like empty containers waiting for tapping the flowing knowledge and information about the targeted language. Hence, the eventual outcome is the accumulation of knowledge as the final product.

One may raise a question hare as to how Saudi English Teachers (SETs) tend to employ traditional teaching practices and methods in the classroom for teaching English. The answer lies in the fact that various factors involving teachers' belief and experiences shape their cognition concerning the process of teaching (Borg, 2003). As EFL learners at school, SETs had been watching the teaching style of their own teachers - Lortie (1975), Lavoire and Roth (2006) term it as "apprenticeship of observation" following the cannons of traditional and behavioristic methods. Even the findings about pre-service programs aiming to change the existing practices of teaching and introducing innovative techniques for making language learning easy in the Saudi school classrooms could not produce the desired results (Hong \& Pawan, 2015). The models followed by SETs led them to evolve their own theories which do not correspond with modern demands of teaching and learning a foreign language like English in Saudi Arabia (Molina, Cañado, \& Agulló, 2013).

\section{CONCLUSION}

Saudi English Teachers (SETs) in the formative phase of their career largely use traditional methods while practicing teaching in EFL classrooms. Though marked with diversification, these methods mainly revolve round GrammarTranslation Method (GMT) and Audio-Lingual Method (ALM). Communicative Language Teaching (CLT) methods as ambitiously driven by the Ministry of Education, Saudi Arabia, are seldom practiced by SETs despite having undergone several training programs. As a result, communicative purpose of EFL learning is not materialized. However, what the Saudi English teachers do in EFL classrooms, do have some positive indicators. As CLT is flexible enough to embrace certain segments of traditional methods, deductive teaching of grammar (GMT) does develop 'linguistic competence'. Simultaneously, developing oral skills by means of controlled practice and repetitive drills (ALM) for teaching discrete skills could help the learners to enhance their communicative competence at a later stage. After all, linguistic competence is a concomitant of communicative competence. Even the preservice programs do contribute as the building blocks of the teaching process for communicative purpose.

It is also concluded that reluctance on the part of the Saudi English teachers (SETs) to implement CLT as teaching practice is not merely because of their perceptions and past experience but other formidable socio-cultural factors also hamper this pursuit. A formal study to explore such factors is also recommended.

\section{REFERENCES}

Alabdualkarem, M. (2007). Teaching English as a foreign language in Saudi Arabia. Riyadh: Obekan Press.

Alseghayer, K. (2011a). English teaching in Saudi Arabia: Status, issues, and challenges. Riyadh, Saudi Arabia: Hala Print Co.

Alseghayer, K. (2011b). Scatter views about English language learning and teaching. Riyadh, Saudi Arabia: Hala print Co. 
ENGLISH REVIEW: Journal of English Education

Volume 7, Issue 2, June 2019

Berns, M. (1990) Context of competence: Social and cultural considerations in communicative language teaching. New York: Plenum.

Birks, M., \& Mills, J. (2011). Grounded theory: A practical guide. London: Sage.

Bowers, B., Nolet, K., Roberts, T., \& Esmond, S. (2007). Implementing change in long-term care: A practical guide to transformation. New York City, NY: Commonwealth Fund.

Breen, M. P., \& Candlin, C. (1980). The essentials of a communicative curriculum in language teaching. Applied Linguistics, 1, 89-112.

Broughton, G., Brumfit, C., Flavell, R., Hill, P., \& Pincas, A. (1994). Teaching English as a foreign language (2nd ed.). London: Routledge.

Brown, H. D. (2007). Teaching by principles: An interactive approach to language pedagogy. New York: Pearson Education Inc.

Canale, M., \& Swain, M. (1980). Theoretical bases of communicative approaches to second language teaching and testing. Applied Linguistics, 1(1), 147.

Chowdhury, M. K. (2012). Communicative language teaching approach at higher secondary level in Bangladesh - Teachers' perceptions and classroom practice. Language in India: Strength for Today and Bright Hope for Tomorrow, 12 (2).

Christopher, D. (2012). The Routledge international handbook of teacher and school development. London: Routledge.

Fantilli, R. D., \& McDougall, D. E. (2009). A study of novice teachers: Challenges and supports in the first years. Teaching and teacher education, 25(6), 814-825.

Fareh, S. (2010). Challenges of teaching English in the Arab world: Why can't EFL programs deliver as expected? Procedia-Social and Behavioral Sciences, 2(2), 3600-3604.

Flowerdew, J., \& Peacock, M. (2001) Research perspectives on English for academic purposes. Cambridge: Cambridge University Press.

Glaser, B., \& Strauss, A. (1967). The discovery of grounded theory: Strategies for qualitative research. Chicago: Aldine.

Hadley, A. O. (2001). Teaching Language in context ( $3^{\text {rd }}$ ed.). Boston: Heinle \& Heinle.

Hong, P., \& Pawan, F. (2015). The pedagogy and practice of western-trained Chinese English language teachers: Foreign education, Chinese meanings. London: Routledge.

Howatt, A. (1984). A history of English language teaching. Oxford: Oxford University Press.

$\mathrm{Hu}$, G. (2002) Potential cultural resistance to pedagogical imports: The case of communicative language teaching in China. Language, Culture, and Curriculum, 15(2), 93-105.

Hymes, D. (1971) Competence and performance in linguistic theory. In R. Huxley and E. Ingram
p-ISSN 2301-7554, e-ISSN 2541-3643

https://journal.uniku.ac.id/index.php/ERJEE

(Eds.), Language acquisition: Models and methods (pp. 3-28). London: Academic Press.

Larsen-Freeman, D. (2001). Techniques and principles in language teaching. New York: Oxford University Press.

Littlewood, W. (1981). Communicative language teaching: An introduction. Cambridge: Cambridge University Press.

Lortie, D. (1975). Schoolteacher: A sociological study. Chicago: University of Chicago Press.

Maria, J. (2006) Classroom L2 vocabulary acquisition: Investigating the role of pedagogical tasks and form-focused instruction. Language Teaching Research, 10(3), pp.263-295.

Molina, G. T. Cañado, M. L. P, \& Agulló, G. L. (2013). Current approaches and teaching methods. Bilingual programmes. University of Jaén, Faculty of Humanities and Education, 4, 156.

Newby, D., (2011). Competence and performance in learning and teaching: Theories and practices. Proceedings of the 19th International Symposium on Theoretical and Applied Linguistics.

Ozsevik, Z. (2010). The use of communicative language teaching (CLT): Turkish EFL teachers' perceived difficulties in implementing CLT in Turkey. Unpublished Master thesis, University of Illinois, Urbana, USA.

Punch, K. F. (2009). Introduction to research methods in education ( $1^{\text {st }}$ ed.). London: Sage.

Rahman, M. M. (2011). English language teaching (ELT) in Saudi Arabia: A Study of learners' needs analysis with special reference to community college, Najran university. Language in India, 11(4), 367-461.

Richards, J. C., \& Rodgers, T. (2001). Approaches and methods in language teaching ( $2^{\text {nd }} e d$.). New York: Cambridge University Press.

Riyadh, Saudi Ministry of Education. (2015). English language teaching, development initiative. Retrieved from http://elt.tatweer.edu.sa/

Welker, R. (1992). The teacher as expert: A theoretical an historical examination. New York: SUNY Press.

Wilkins, D. A. (1976). Notional syllabuses. Oxford: Oxford university Press. 
Majed Othman Aba Hussain, Muhammad Iqbal, \& Imran Khan

Efficacy of methodological practices undertaken by Saudi English teachers in public schools during their formative phase 